\title{
Editorial
}

\section{Covid-19 and Pregnancy}

\section{Yudianto B. Saroyo}

It has been a year since Covid-19 (coronavirus disease of 2019) or severe acute respiratory syndrome coronavirus 2 (SARS-CoV-2) firstly reported in Wuhan, China. ${ }^{1}$ This infection indiscriminately affect from neonate until the elderly, and pregnant women also inevitable. Since March 2020, WHO has already declared this situation as a pandemic. ${ }^{2}$ Covid- 19 contagion can transmit into two methods, close contact from infected people, the droplet dispersion into the mouth, eye, nose, or airway tract until the alveoli, touch from a specific object that contains the virus then the person sweep the mouth, nose or the eye. ${ }^{3}$ The virus is single-stranded RNA with 4 structural proteins, S (spike), E (envelope), N (nucleocapsid), and $\mathrm{M}$ (membrane). A crucial point in the pathogenesis is the binding between S protein to the ACE 2 receptor in the pneumocyte at alveoli. Subsequently, endocytosis happens and virus RNA is released and replication takes place inside the cell. Eventually, the new virus will be released and it will infect another cell. And it will provoke some immunologic reaction inside alveoli and in blood circulation. ${ }^{4}$

Then, how about in pregnant women? The maternal immune system more susceptible to Covid-19 infection due to in these conditions undergo decrease of lymphocyte, NGK2A inhibitor receptor, and increase of ACE2, IL-9, IL-10, and IP-10 receptors. ${ }^{5}$ Like another maternal infection, the first thing in mind is there any vertical transmission to the fetus? The scientific report already stated that vertical transmission to the fetus is low, around 3.2\% in third-trimester mother with Covid-19 infection, without an adverse event to the neonate. ${ }^{6}$ Beside of ACE2 receptor in the placenta, $\mathrm{N}$ and S proteins is highly expressed in the placenta in confirmed case mother. ${ }^{7}$ Thus far, Covid-19 infection does not correlate with the neonatal poor outcome but somehow isolates the mother from the baby have an important role to cut off the transmission. ${ }^{8}$ However, Covid-19 is related to an increased risk of preterm labor and fetal distress. ${ }^{9}$ It is still controversy in the delivery method with Covid-19 infection. Until now, no recommendation for the best method for delivery concerning better outcome for the mother and also prevention vertical transmission. The delivery method selection should consider the availability of health care providers, hospital facility, spatial room of care, procurement of personal protective equipment (PPE), ability to implement, human resources, and exposure risk of infection. It will influence the physician who took care of the patient, to determine the suitable method of delivery for each patient. Rooming-in can be performed in Covid-19, the transmission risk to the baby is low, and no risk discrepancy SARS-CoV-2 infection in rooming-in baby and not rooming-in. ${ }^{10}$ No evidence that the virus is discovered in the breastmilk. Breastmilk gives important nutrition for the baby. Nevertheless, in this pandemic era, the Indonesian Pediatric Association recommends a discussion and decision in conjunction with healthcare, mother, and family. The recommendation contraception in mother after delivery is long-acting reversible contraceptive (LARC) method and can be given right after delivery like intrauterine device or implant. In the patient with Covid-19 with hormonal contraception, some of these drugs have such drug interactions. It will affect the favipiravir clearance, baricitinib and sarilumab will decrease the level and activity of hormonal contraception, while lopinavir/ritonavir will increase hormonal contraception in blood. No data regarding in concomitant with remdesivir use. Meanwhile, tocilizumab has no interaction with hormonal contraception. ${ }^{11}$ Another issue is regarding maternal vaccination. Some pharmaceutical companies have already performed research on the Covid-19 vaccine. So far, just one vaccine has been published phase 3 trial from BNT162b2 mRNA with protection claim until $95 \% .{ }^{12}$ Unfortunately, this study has not proven the efficacy in pregnant women. The vaccination program in pregnant women is not only to give protection or prevention to the mother but also to prevent congenital infection and neonatal infection. ${ }^{13}$ It is very interesting to await in the future months, whether the vaccine can protect not only the general adult population but also pregnant women and the neonate. 


\section{REFERENCES}

1. https://www.who.int/csr/don/12-january-2020-novel-coronavirus-china/en/.Last accessed December 15 th 2020.

2. https://www.who.int/director-general/speeches/detail/who-director-general-s-opening-remarks-at-the-mediabriefing-on-covid-19---11-march-2020. Last accessed December 15th 2020.

3. WHO: Coronavirus disease 2019 (COVID-19) situation report-55. In., March 15, 2020 edn. 2020 https://www.who.int/ docs/default-source/coronaviruse/situation-reports/20200315-sitrep-55-covid-19.pdf?sfvrs n=33daa5cb_8.

4. Kumar, Manoj, and Souhaila Al Khodor. "Pathophysiology and treatment strategies for COVID-19." J. Translational Med. 2020; 18 (1): 1-9.

5. Khaliq, Olive P., and Wendy N. Phoswa. "Is pregnancy a risk factor of COVID-19?." Eur J Obstet Gynecol Reprod Biol. 2020;252:605-9.

6. Fornari, Federico. "Vertical transmission of Covid-19-A systematic review." J Pediatr Perinatol Child Health.2020; 4: 7-13.

7. Facchetti F, Bugatti M, Drera E, Tripodo C, Sartori E, Cancila V, et al. SARS-CoV2 vertical transmission with adverse effects on the newborn revealed through integrated immunohistochemical, electron microscopy and molecular analyses of Placenta. Ebio Med. 2020;59:102951.

8. Yang P, Wang X, Liu P, Wei C, He B, Zheng J, et al. Clinical characteristics and risk assessment of newborns born to mothers with COVID-19. J Clin Virol. 2020;127:104356.

9. Ashraf, Mohammad Ali, et al. "Coronavirus disease 2019 (COVID-19): a systematic review of pregnancy and the possibility of vertical transmission." J Reprod Infertil. 2020;21(3): 157.

10. https://www.cdc.gov/coronavirus/2019-ncov/hcp/caring-for-newborns.html\#mother-neonatal-contact. Last accessed December 16th 2020.

11. Ferreira-Filho, Edson Santos. "Contraception and reproductive planning during the COVID-19 pandemic." Expert Review Clin Pharmacol. 2020; 13 (6): 615-22.

12. Fernando P. Polack, Steven J. Thomas, Nicholas Kitchin, et al. "Safety and efficacy of the BNT162b2 mRNA covid-19 vaccine." New Engl J Med. 2020:1-13.

13. Vermillion, Meghan S., and Sabra L. Klein. "Pregnancy and infection: Using disease pathogenesis to inform vaccine strategy." NPJ Vaccines. 2018; 3(1): 1-11. 